\title{
Antioxidant and Anticancer Study of Boerhavia erecta
}

\author{
M. Ismail Shareef, S.M. Gopinath", Ayushi Gupta and Sonia Gupta \\ Department of Biotechnology, Acharya Institute of Technology, Bangalore, Karnataka, India \\ *Corresponding author
}

\section{A B S T R A C T}

Keywords

Boerhavia erecta, DPPH, Nitric oxide Scavenging activity, Cytotoxicity, MTT assay.

Article Info

Accepted:

14 July 2017

Available Online:

10 September 2017
Boerhavia erecta, an annual herb, has been used in folklore for managing of a wide range of diseases including cancer. However, the safety and effectiveness of this medicinal plant was better evaluated. The intention of this study was to evaluate the in-vitro antioxidant and anticancer activities of whole plant extract of Boerhavia erecta well as the qualitative phytochemical constituents. The DPPH and nitric oxide scavenging assays were used to evaluate the plant's antioxidant potential. The in-vitro3-(4, 5- Dimethylthiazol-2-yl)-2, 5-Diphenyltetrazolium Bromide (MTT) assay was exploited for determination of in-vitro anticancer activity against two cell lines: Mouse fibroblastic cell lines (L929), it's a normal cell line and human brain tumor cell lines (U87), it's a cancer cell line. Ascorbic acid and quercetin were used a standard antioxidant compound. The IC50 and CTC50 values were also estimated for antioxidant and anticancer studies respectively.

\section{Introduction}

Over the past two decades, medicinal plant has gained attention as natures cure for human cancer, is a major reason for the human mortality rate [1], especially with a growing number of population in the world.

In 2012, 40\% of the developed antitumor agents are either natural products or modified natural products. Some of these have been correlated with antioxidant activities [2].

Antioxidants are the major plant products that play a major role in anticancer agents through acting as reducing agents, hydrogen donators, DPPH, nitric oxide free radical scavenging activity, etc. [3].
Anticancer agents mainly exhibit a preventative or curative role in a damaged system. Under normal conditions, the cells in which the DNA or other components were irreversibly damaged by various causes, undergo programmed cell death (apoptosis) [4].

The aim of anticancer agents is to trigger the apoptosis signaling system in these cancer cells which controls their proliferation [5].

Current research therefore seeks for novel natural products from most known medicinal plant sources that exhibit anticancer activities based on ethnobotanical or ethnomedical 
studies which reveal scared prescriptions and folkloric beliefs inherited through generations [6].

Boerhaviaerecta, commonly known as the erect spiderling, erect boerhavia, Hindi Shweta and Marathi pandharipunarnava. It is an herbaceous member of the family Nyctaginaceae and mainly used as a traditional medicinal plant in Africa [7].

Boerhaviadiffusa is also an herbaceous member of the family Nyctaginaceae which has some similar properties, so from the pharmacological studies it is demonstrated that it possesses a diuretic [8], antiinflammatory [9], antifibrinolytic [10], anticonvulsant [11] and hepatoprotective activities [12and13] these all properties are very useful to make a perfect medicinal plant.

In moderate doses, it was useful in the treatment of asthma [14]. In West and East Africa, the leaves are eaten as a vegetable or used for the preparation of sauces [15].

The focus of this research was to access invitro antioxidant and anti-cancer activities of crude methanolic extract of whole plant Boerhaviaerecta.

\section{Materials and Methods}

\section{Cell lines and reagents}

Mouse fibroblastic cell lines (L929) and Human brain glioblastoma cell lines (U87) were obtained from ATCC (Animal Tissue Cell Culture). Dimethyl sulphoxide (DMSO), 2, 2-Diphenly 1-picryl hydroxyl solution (DPPH), Methanol, Sodium nitroprusside solution, Naphthyl ethylene diaminedihydrochloride (NEDD), Sulphanilic acid, PBS (pH 7.4), 3-(4, 5-dimethylthiazol-2yl) 2, 5-diphenyltetrazolium bromide (MTT) dye, etc.

\section{Cell culture}

The cell lines were cultured as slightly described modifications [16]. The L929 cell lines were cultured in MEM medium and U87 cell lines were cultured in Ham's F12 medium. All culture media were supplemented with $1 \%$ penicillin streptomycin L-glutamine (PSG) and $8 \%$ fetal bovine serum (FBS). The cells were maintained in a $5 \% \quad \mathrm{CO}_{2}$ incubator at $37^{\circ} \mathrm{C}$ and sub-cultured on reaching about $70-80 \%$ confluency.

\section{Plant material and extraction}

Boerhavia erecta plant was collected from the district of Tamil Naidu. Boerhaviaerecta plant was dried and weighed approximately 270 gm along with $2.5 \mathrm{~L}$ methanol solvent. The extraction process was done by hot continuous extraction method using soxhlet apparatus (Figure 1). The process of transferring the partially soluble components of a solid to the liquid phase using a soxhlet extractor. The solid was placed in a filter paper thimble which was then placed into the main chamber of the soxhlet extractor. The solvent (heated to reflux) travels into the main chamber and the partially soluble components are slowly transferred to the solvent.

\section{In-vitro antioxidant activity}

\section{DPPH scavenging activity}

The effect of crude extract of Boerhavia erecta on the scavenging activity of DPPH were determined as earlier slightly modification [17]. Carry out the assay in a 96 well microtiter plate. Add $200 \mu \mathrm{l}$ of methanolic DPPH solution in triplets as test and control and add $200 \mu \mathrm{l}$ of methanol as test blank and control blank in singlet. To that add $10 \mu \mathrm{l}$ of each of the test substance or the standard from the lowest concentration and 10 
$\mu 1$ DMSO serves as control and control blank. Use $1000,500,250,125,62.5 \mu \mathrm{g} / \mathrm{ml}$ as final concentration of the test and standard solutions. Incubate the plates at $37^{\circ} \mathrm{C}$ for 30 minutes. Take the absorbance of each solution at $490 \mathrm{~nm}$ and record the values [18].

\section{Nitric oxide free radical scavenging activity}

The effect of crude extract of Boerhavia erecta on the scavenging activity of nitric oxide were determined as earlier slightly modification [17]. Incubate the reaction mixture $(0.6 \mathrm{ml})$ in $1.5 \mathrm{ml}$ centrifuge tubes containing sodium nitroprusside $(10 \mathrm{mM}, 0.4$ $\mathrm{ml}$ ), phosphate buffer saline (PBS, pH 7.4, 0.1 $\mathrm{ml}$ ) and $0.1 \mathrm{ml}$ of test substance or standard in DMSO of various concentrations as test and $0.1 \mathrm{ml}$ of DMSO as control at $25^{\circ} \mathrm{C}$ for 150 minutes.

Use $1000,500,250,150,62.5 \mu \mathrm{g} / \mathrm{ml}$ as final concentration of the test and standard solution. Follow the same procedure for test blank and control blank. In place of sodium nitroprusside, take distilled water. After incubation, pipette out $0.05 \mathrm{ml}$ of the reaction mixture containing nitrite ion from centrifuge tubes and transfer to microtiter plate in triplets as test, control. Make control blank and test blank in singlet. Add $0.1 \mathrm{ml}$ of sulphanilic acid reagent to all the wells, mix well and allow it to stand for $5 \mathrm{~min}$ for completion of diazotization. Then, add $0.1 \mathrm{ml}$ of NEDD, mix and allow it to stand for 30 minutes in diffused light. A pink colored chromophore will be formed. Take the absorbance of these solutions at $540 \mathrm{~nm}$ and record the values [18].

\section{In-vitro cytotoxicity (MTT) assay}

The in-vitro cytotoxicity of the crude extract was performed on L929 cell lines and U87 cell lines as described [19].

Day 1: Seed the cells in a 96 well plate in three rows with the average cell density of
10,000 cells per well. Incubate the 96 well culture plate at $37^{\circ} \mathrm{C}$ in $\mathrm{CO}_{2}$ incubator overnight.

Day 2: Made the stock solution of plant extract (drug) in DMSO with concentration of $10 \mathrm{mg} / 100 \mu \mathrm{l}$. Dissolve it properly in the sonicator. From this stock solution, prepared five different dilution of plant extract in the complete Ham's F12 media (U87 cell lines) and MEM media (L929 cell lines) using multichannel reservoir. Dilutions were 1000, $500,250,125$ and $65.2 \mu \mathrm{g} / \mathrm{ml}$. Removed the media from the 96 well seeded plate. Added the media containing different dilutions of plant extract as made above. For control wells, add only media. Incubate the 96 well culture plate at $37^{\circ} \mathrm{C}$ in $\mathrm{CO}_{2}$ incubator overnight.

Day 3: Observed the treated cells under inverted microscope. Prepared MTT reagent by adding MTT powder in phosphate buffer saline $(\mathrm{pH} 7.2)$ in concentration of $5 \mathrm{mg} / 10 \mathrm{ml}$. Removed the media and add $100 \mu 1$ MTT reagent in all 96 well plate. Incubate it at $37^{\circ} \mathrm{C}$ in $\mathrm{CO}_{2}$ incubator for 3-4 hrs.

Removed the MTT reagent and add $100 \mu \mathrm{l}$ DMSO for solubilizing the formazan produced. Shake the plate well and took the absorbance reading at $490 \mathrm{~nm}$.

Inhibition percentage was calculated by the following formula-

$\%$ inhibition $=($ control cells absorbance-drug cells absorbance)/ control cells absorbance * 100

\section{Results and Discussion}

\section{In vitro antioxidant activity}

In DPPH assay, the test sample showed moderate activity when compared to the standard antioxidant quercetin (Table 1). 


\section{Nitric oxide free radical scavenging activity}

In nitric oxide assay, the test sample showed very poor antioxidant activity as compared to the standard ascorbic acid (Table 2).

\section{In vitro cytotoxicity (MTT) assay}

The Boerhavia erecta extract showed CTC50 value of $902.99 \mu \mathrm{g} / \mathrm{ml}$ and $945.65 \mu \mathrm{g} / \mathrm{ml}$ respectively in a dose-dependent manner on the growth in U87 cell lines and L929 cell lines respectively(Tables 3 and 4). The search for novel natural antioxidants constitutes as geared by safety considerations, public's perception and risk reduction of chronic diseases by consumption of edible fruits and vegetables.

Antioxidants can protect the body by preventing the formation of free radicals through interruption of free radical's attack, or by scavenging the reactive metabolites or converting then to less reactive molecules [21].

Table.1 DPPH assay results

\begin{tabular}{|l|l|}
\hline Concentration $(\boldsymbol{\mu g} / \mathbf{m l})$ & Average \% inhibition \\
\hline 1000 & 77.11 \\
\hline 500 & 45.71 \\
\hline 250 & 21.83 \\
\hline 150 & 13.49 \\
\hline 62.5 & 5.41 \\
\hline Control & 0.00 \\
\hline IC50 value & 567.501 \\
\hline
\end{tabular}

Table.2 Nitric oxide scavenging results

\begin{tabular}{|l|l|}
\hline Concentration $(\boldsymbol{\mu g} / \mathbf{m l})$ & Average \% inhibition \\
\hline 1000 & 51.04 \\
\hline 500 & 36.80 \\
\hline 250 & 25.52 \\
\hline 150 & 18.87 \\
\hline 62.5 & 12.71 \\
\hline Control & 0.00 \\
\hline IC50 value & 965.8748 \\
\hline
\end{tabular}

Table.3 Cytotoxicity effect of Boerhavia erecta plant extract on U87 cell lines

\begin{tabular}{|l|l|}
\hline Conc. $(\boldsymbol{\mu g} / \mathbf{m l})$ & Average \% inhibition \\
\hline 1000 & 56.50 \\
\hline 500 & 22.99 \\
\hline 250 & 11.19 \\
\hline 150 & 5.88 \\
\hline 62.5 & 1.30 \\
\hline Control & 0.00 \\
\hline CTC50 value & 902.99 \\
\hline
\end{tabular}


Table.4 Cytotoxicity effect of plant extract on L929 cell lines

\begin{tabular}{|l|l|}
\hline Conc. $(\boldsymbol{\mu g} / \mathbf{m l})$ & Average\% inhibition \\
\hline 1000 & 52.82 \\
\hline 500 & 26.93 \\
\hline 250 & 18.74 \\
\hline 150 & 8.99 \\
\hline 62.5 & 3.58 \\
\hline Control & 0.00 \\
\hline CTC50 value & 945.65 \\
\hline
\end{tabular}

Graph.1 \% inhibition of plant extract

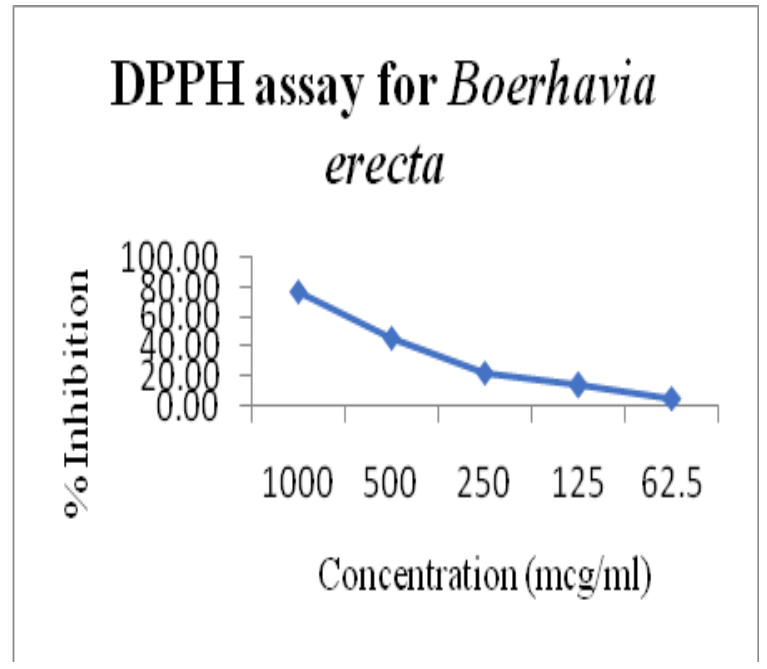

Graph.3\% inhibition of plant extract on U87 cell line



Graph.2\% inhibition of plant extract

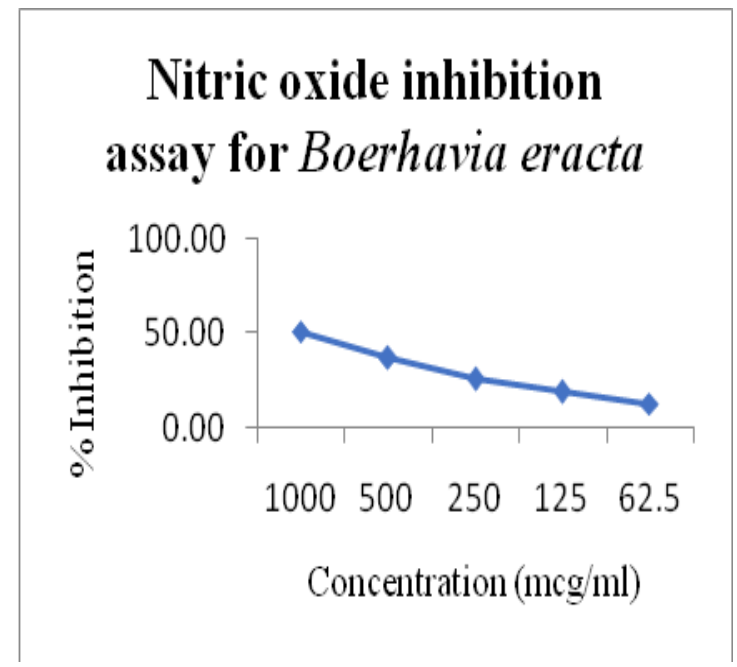

Graph.4\% inhibition of plant extract on L929 cell lines

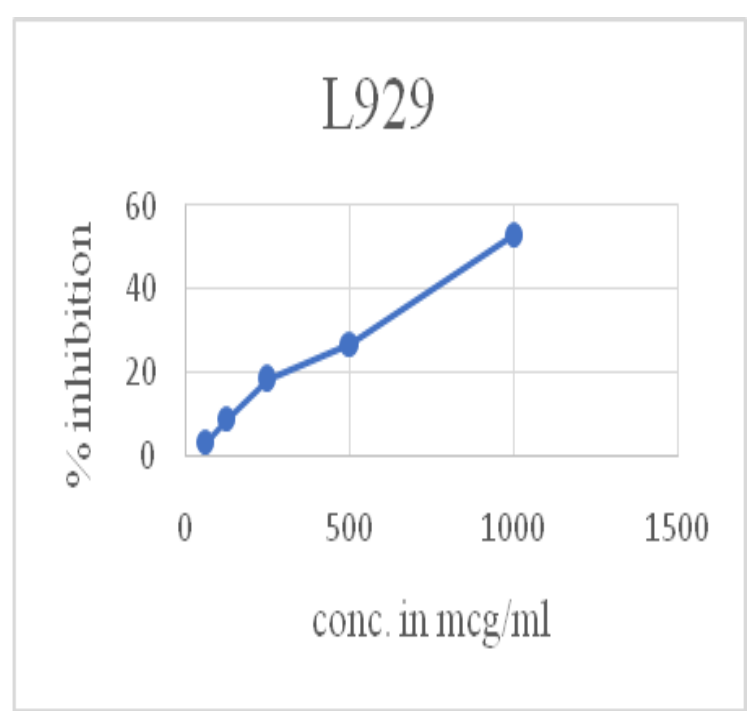


Fig.1 Soxhlet extraction apparatus



The present study, in-vitro antioxidant and anticancer activities of $B$. erecta, using crude methanolic extract of the whole plant, were reported for the first time.

The results of the present investigations have shown that whole plant of methanolic extract of $B$. erecta possesses better antioxidant results in DPPH as compared to nitric oxide free radical scavenging activity. Anticancer activity showed better results in both the cell lines i.e. U87 and L929.

\section{Acknowledgment}

The authors were grateful to Acharya Institute of Technology and Radiant Research Services Pvt. Ltd. for providing necessary chemicals and equipment's for the completion of following work.

\section{References}

1. World Health Organization, \& International Agency for Research on Cancer. (2014). Global battle against cancer won't be won with treatment alone: Effective prevention measures urgently needed to prevent cancer crisis, [Press Release]. London: WHO IARC. Retrieved February 10, 2014
2. Elansary, H. O. (2014). Natural Antioxidants and their Role against Human Cancer. J Plant Biochem Physiol, 2(2), 125.

3. Shimizu, T., Torres, M. P., Chakraborty, S., Souchek, J. J., Rachagani, S., Kaur, S., ... \& Batra, S. K. (2013). Holy Basil leaf extract decreases tumorigenicity and metastasis of aggressive human pancreatic cancer cells in vitro and in vivo: Potential role in therapy. Cancer letters, 336(2), 270280.

4. Lee, J. Y., Hwang, W. I., \& Lim, S. T. (2004). Antioxidant and anticancer activities of organic extracts from Platycodon grandiflorum A. De Candolle roots. Journal of Ethnopharmacology, 93(2), 409-415.

5. Ghobrial, I. M., Witzig, T. E., \& Adjei, A. A. (2005). Targeting apoptosis pathways in cancer therapy. CA: a cancer journal for clinicians, 55(3), 178-194.

6. Ravindran, J., Prasad, S., \& Aggarwal, B. B. (2009). Curcumin and cancer cells: how many ways can curry kill tumor cells selectively? The AAPS journal, 11(3), 495510.

7. Stintzing, F. C., Kammerer, D., Schieber, A., Adama, H., Nacoulma, O. G., \& Carle, R. (2004). Betacyanins and phenolic compounds from Amaranthus spinosus L. 
and Boerhavia erecta L. Zeitschrift für Naturforschung C, 59(1-2), 1-8.

8. Gaitonde, B. B., Kulkarni, H. J., \& Nabar, S. D. (1974). Diuretic activity of Punarnava (Boerhavia diffusa). Bull Haffkine Inst, 2.

9. Bhalla, T. N., Gupta, M. B., Seth, P. K., \& Bhargava, K. P. (1968). Anti-inflammatory activity of Boerhaavia diffusa.

10. Jain, G., \& Khanna, N. (1989). Punarnavoside: a new fibrinolytic agent from Boerhaavia diffusa Linn. Indian $J$. Chem. B, 28, 163-166.

11. Adesina, S. K. (1979). Anticonvulsant properties of the roots of Boerhaavia diffusa Linnaeus. Quarterly Journal of Crude Drug Research, 17(2), 84-86.

12. Chandan, B. K., Sharma, A. K., \& Anand, K. K. (1991). Boerhaavia diffusa: a study of its hepatoprotective activity. Journal of Ethnopharmacology, 31(3), 299-307.

13. Rawat, A. K. S., Mehrotra, S., Tripathi, S. C., \& Shome, U. (1997). Hepatoprotective activity of Boerhaavia diffusa L. roots-a popular Indian ethnomedicine. Journal of Ethnopharmacology, 56(1), 61-66.

14. Schmelzer, G. H. (2006). Boerhavia erecta L. PROTA (Plant Resources of Tropical Africa/Ressources végétales de l'Afrique tropicale), Wageningen (http://database. prota. org/search. htm, Date of access: 1 October 2008).

15. Grubben, G. J. (2004). Plant Resources of Tropical Africa (PROTA) (Vol. 1). Prota.

16. Ham, Y. M., Yoon, W. J., Park, S. Y., Jung, Y. H., Kim, D., Jeon, Y. J., ... \&
Kim, K. N. (2012). Investigation of the component of Lycopodium serratum extract that inhibits proliferation and mediates apoptosis of human HL-60 leukemia cells. Food and chemical toxicology, 50(8), 2629-2634.

17. Brand-Williams, W., Cuvelier, M. E., \& Berset, C. L. W. T. (1995). Use of a free radical method to evaluate antioxidant activity. LWT-Food science and Technology, 28(1), 25-30.

18. Jaishree Vaijanathappa, Shrishailappa Badami., Sauresh Bhojaraj., (2008) In Vitro antioxidant activity of enicostemma axillare. J. Health Science. Vol 54 (5) pp $524-528$

19. Ayisi, N. K., Appiah-Opong, R., Gyan, B., Bugyei, K., \& Ekuban, F. (2011). Plasmodium falciparum: assessment of selectivity of action of chloroquine, Alchornea cordifolia, Ficus polita, and other drugs by a tetrazolium-based colorimetric assay. Malaria research and treatment, 2011.

20. Dastmalchi, K., Dorman, H. D., Koşar, M., \& Hiltunen, R. (2007). Chemical composition and in vitro antioxidant evaluation of a water-soluble Moldavian balm (Dracocephalum moldavica L.) extract. LWT-Food Science and Technology, 40(2), 239-248.

21. Hegde, K., \& Joshi, A. B. (2009). Hepatoprotective effect of Carissa carandas Linn root extract against $\mathrm{CCl} 4$ and paracetamol induced hepatic oxidative stress.

\section{How to cite this article:}

Ismail Shareef, M., S.M. Gopinath, Ayushi Gupta and Sonia Gupta. 2017. Antioxidant and Anticancer Study of Boerhavia erecta. Int.J.Curr.Microbiol.App.Sci. 6(9): 879-885. doi: https://doi.org/10.20546/ijcmas.2017.609.106 